\title{
Comunicação e sensibilidade: reflexões estéticas
}

\author{
DOI: 10.1590/1809-58442019313
}

\author{
Antonio Bastos ${ }^{1}$ \\ https://orcid.org/0000-0003-3058-8653

\section{Gabriela Borges ${ }^{1}$} \\ https://orcid.org/0000-0002-0612-9732
}

${ }^{1}$ (Universidade Federal de Juiz de Fora, Faculdade de Comunicação, Programa de Pós-Graduação em Comunicação. Juiz de Fora - MG - Brasil).

VALVERDE, M. Pequena estética da comunicação. 1. ed. Salvador: Arcádia, 2017.

Professor titular do Instituto de Humanidades, Artes e Ciências da Universidade Federal da Bahia (UFBA), Monclar Valverde, em sua obra "Pequena Estética da Comunicação" (VALVERDE, 2017), se debruça em mais um movimento reflexivo sobre as particularidades da relação entre o sensível e o comunicacional. O autor situa a obra como uma retomada sintética de seu livro “Estética da Comunicação” (VALVERDE,

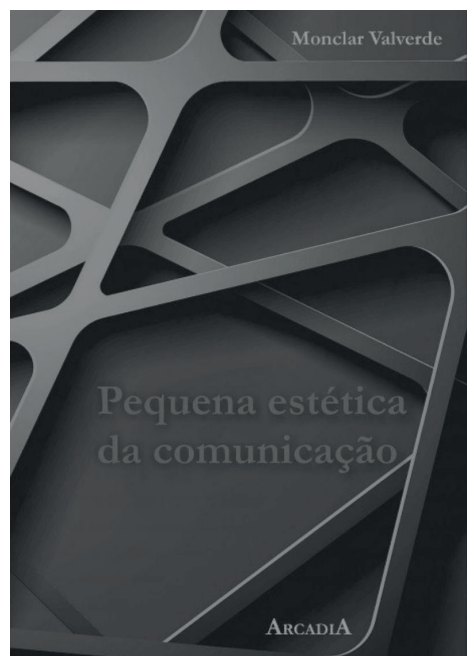
2007), entendendo que a discussão desenvolvida naquele primeiro esforço merecia uma segunda chance. Para construir tal discussão, o autor recorreu a uma divisão da obra em duas partes: a primeira lança o foco na questão da sensibilidade e tecnologia na experiência estética; e a segunda se volta para as noções de gosto e formatividade nas áreas da Arte e da Comunicação.

Valverde (2017) inicia a primeira parte tratando da relação entre comunicação e experiência, situando a experiência nova em uma condição de transformação, algo que escaparia da redundância do campo de experiências prévias e que, mesmo que mediada ou não vivenciada diretamente, poderia gerar sentido e ser compreendida por um sujeito.

É desse ponto que o autor parte para a primeira discussão chave do livro: a relação da subjetividade e da objetividade com o processo de comunicação. Entendendo que a tradição e os costumes a partir dos quais somos educados agem sobre nós para além das referências conceituais e do nosso repertório, Valverde (2017, p. 15) considera que esse fundo cultural age como "um modo inconsciente de estruturação", concebendo a nossa forma de perceber, compreender e julgar o mundo do qual fazemos parte, de certa forma ocupando também o processo de desenvolvimento do que reconhecemos como subjetividade. Já no campo da objetividade e sua relação com a comunicação, o autor cita a tendência que 
estudos anteriormente consolidados tiveram em subestimar o caráter específico das formas de comunicação contemporâneas, construindo o conhecimento da área com bases formais e duras de análise e compreensão da nossa relação com os media.

Nesse contexto, é relevante recorrer a McLuhan e sua noção dos meios como extensões do homem, para reconhecer que essa relação entre sujeito e comunicação (midiática ou interpessoal) faz parte de uma ambiência que envolve de maneira dinâmica as nossas ações e que também formata, no âmbito cultural, a já citada forma de perceber o mundo e criar sentido a partir dele. Surge, então, a necessidade de reconhecer o papel do corpo nessa ambiência dinâmica, não apenas como receptáculo sensível, mas, também, como sede de significação e de construção ativa e sinestésica da nossa relação com o exterior. Não estamos fora do mundo; ao percebê-lo, participamos dele.

Dando prosseguimento à discussão, Valverde (2017) novamente referencia McLuhan, dessa vez em articulação com Benjamin, para pensar a relação entre sensibilidade e tecnologia. Ainda que ambos os autores tratem das mudanças que novas tecnologias (e, nesse caso, especialmente novos meios de comunicação) podem causar na nossa sensibilidade, é necessário reconhecer que nem toda nova tecnologia gera necessariamente uma nova faculdade sensível. O desenvolvimento tecnológico parece não possuir limites, de maneira que, considerar que a expansão da nossa sensibilidade acompanha esse ritmo ilimitado resultaria numa banalização do caráter transformador necessário para a ocorrência de experiências estéticas.

A ideia de que a sensibilidade não pode ser pensada a partir de parâmetros cartesianos é reforçada ao longo do texto por uma proposta constante de relativização que busca tensionála junto a noções de entendimento comumente associadas ao pensamento racional. Esse tensionamento se revela como a base necessária para a reflexão estética.

No centro dessa proposta de relativização, talvez esteja o pensar sobre a comunicação contemporânea e seu espaço digital. Esse espaço aproximaria a arte e a tecnologia em um processo que não diz respeito somente aos avanços e possibilidades técnicas de produção artística, mas, também, ao caráter estético e sensível reconfigurado (embora não revolucionado) nesse espaço.

O artista, num contexto digital ou não, na medida em que desenvolve a sua obra, também a frui, a percebe ainda como inacabada, até que decida pelo desfecho do processo. Tratando da formatividade artística, conceito trabalhado por Pareyson (1992), Valverde (2017) coloca que a ideia de construção e produção deve ser pensada como um processo não totalmente "ativo", inovador, mas como algo inserido em um contexto cultural e permeado, na experiência do próprio artista, de fruição e também recepção.

O sentido de conhecimento atribuído à arte também deve ser repensado, partindo de uma reflexão etimológica que o considere “co-nascimento”, um nascimento simultâneo do sujeito e do objeto, não havendo dicotomia entre ambos. A ideia de expressão também deve superar sua conotação romântica de exteriorização de uma subjetividade, cabendo reconhecer que o sujeito é indissociável da mesma, se reconhecendo nela e através dela. 
Nesse processo complexo, o criador, assim como o jogador, parte para o investimento formativo carregado de um elemento lúdico. Ambos os agentes produzem no limiar de uma tensão entre o padrão e o desvio. Não há um grau de experiência nula, somos acolhidos por uma experiência coletiva a partir do momento que existimos no mundo e a tensionamos em toda atividade criativa. Daí a inconsistência de uma utopia vanguardista, que cobra originalidade e quebra de padrões em cada movimento desse tipo.

Considerando que o processo comunicacional depende do compartilhamento de um "sentimento de existência” (VALVERDE, 2017, p. 133) e que essa comunhão estética é que o permite o exercício do gosto e a consolidação de um senso comum, torna-se importante observar que existe algo de transcendental na comunicação. Esse elemento que ultrapassa o empírico teria sido ignorado por boa parte da produção de conhecimento da área, sendo objeto central da Estética da Comunicação.

Toda a construção conceitual e histórica trazida por Valverde (2017) resulta, então, na defesa desse transcendental relacionado à sensibilidade como centro das reflexões sobre o processo comunicacional. A recepção estética consistiria num "jogo entre sensibilidade, entendimento e imaginação, no qual forma, sentido e valor se reenviam continuamente” (VALVERDE, 2017, p. 131).

Esse compartilhamento de sentido no qual todos somos inseridos a partir da nossa presença no mundo não é reduzido à transmissão de ideias, mas diz respeito ao sentimento próprio de existência, de ser no mundo, ao ato de criar e tensionar as nossas referências nessa comunhão sensível.

\section{Referências}

PAREYSON, L. Estética: teoria da formatividade. Tradução de Ephraim Ferreira Alves. Petrópolis: Vozes, 1992.

VALVERDE, M. Estética da Comunicação. Salvador: Quarteto, 2007.

VALVERDE, M. Pequena estética da comunicação. 1. ed. Salvador: Arcádia, 2017.

\section{Antonio Bastos}

Graduado em Comunicação Social - Publicidade e Propaganda pela Universidade Federal do Pará. Mestrando do Programa de Pós-Graduação em Comunicação da Universidade Federal de Juiz de Fora. E-mail: bastosantonio33@gmal.com.

\section{Gabriela Borges}

Doutora e Mestre em Comunicação e Semiótica pela PUC-SP, com estágios nas Universidades Autônoma de Barcelona, Dublin Trinity College e Algarve. Possui pós-doutorado pela Universidade 
do Algarve em Portugal. Professora e vice-coordenadora do Programa de Pós-Graduação em Comunicação da Universidade Federal de Juiz de Fora. E-mail: gabriela.borges@ufjf.edu.br.

Recebido em: 18.05.2019

Aprovado em: 26.07.2019 